\title{
Different immunosuppressive mechanisms in multi-drug-resistant tuberculosis and non-tuberculous mycobacteria patients
}

R. O. Pinheiro, ${ }^{\star}$ E. B. de Oliveira, ${ }^{\star}$

G. dos Santos, ${ }^{\dagger}$ G. M. Sperandio da Silva, ${ }^{\ddagger}$ B. J. de Andrade Silva, ${ }^{*}$ R. M. B. Teles, ${ }^{\star}$ A. Milagres, ${ }^{\$}$

E. N. Sarno, ${ }^{\star}$ M. P. Dalcolmo ${ }^{\dagger}$ and E. P. Sampaio*9

${ }^{*}$ Leprosy Laboratory, Instituto Oswaldo Cruz, Oswaldo Cruz Foundation, Fiocruz, ${ }^{\dagger}$ Helio Fraga Reference Center, ENSP/Fiocruz, ${ }^{\ddagger}$ Chagas Laboratory, Evandro Chagas Institute of Clinical Research, IPEC/Fiocruz, ${ }^{\S}$ Health Unit, District Hospital Raphael de Paula Souza, Rio de Janeiro, Brazil, and 'Immunopathogenesis Section, Laboratory of Clinical Infectious Diseases, LCID/NIAID, National Institutes of Health, NIH, Bethesda, WA, USA

Accepted for publication 10 October 2012 Correspondence: E. P. Sampaio, LCID, NIH, CRC B3-4233, MSC 1684, Bethesda, MD 20892-1684, USA.

E-mail: sampaioe@niaid.nih.gov

\begin{abstract}
Summary
Previous studies have demonstrated that cells from both multi-drugresistant tuberculosis (MDR-TB) and non-tuberculous mycobacteria (NTM) patients respond poorly to mycobacterial antigens in vitro. In the present study, we compared the in vitro response of cells isolated from sensitive TB (NR-TB)-, MDR-TB- and NTM-infected patients. Analysis of T cell phenotype ex vivo revealed that both MDR-TB and NTM patients present an increased percentage of $\mathrm{CD} 4^{+} \mathrm{CD} 25^{+-}$forkhead box protein $3(\mathrm{FoxP} 3)^{+}$and $\mathrm{CD} 4^{+} \mathrm{CD} 25^{+} \mathrm{CD} 127^{-}$regulatory $\mathrm{T}\left(\mathrm{T}_{\text {reg }}\right)$ cells when compared to NR-TB. Increased numbers of $\mathrm{T}_{\text {reg }}$ cells and interleukin (IL)-10 serum levels were detected in MDR-TB, whereas elevated serum transforming growth factor (TGF) $\beta$ was found in the NTM group. Cells of MDR-TB patients stimulated with early secretory antigenic target (ESAT)-6, but not purified protein derivative (PPD), showed a lower frequency of $\mathrm{CD} 4^{+} /$interferon (IFN) $\gamma^{+} \mathrm{T}$ cells and enhanced $\mathrm{CD} 4^{+} \mathrm{CD} 25^{+} \mathrm{FoxP}^{+}, \mathrm{CD} 4^{+} \mathrm{CD} 25^{+} \mathrm{CD} 127^{-}$and $\mathrm{CD}^{+} \mathrm{CD} 25^{+} \mathrm{IL}-10^{+} \mathrm{T}$ cell population. In addition, increased IL-10 secretion was observed in cultured MDR-TB cells following ESAT-6 stimulation, but not in NR-TB or NTM patients. In vitro blockade of IL-10 or IL-10R $\alpha$ decreased the $\mathrm{CD}^{+} \mathrm{CD} 25^{+} \mathrm{FoxP}^{+}$frequencies induced by ESAT- 6 in MDR$\mathrm{TB}$, suggesting a role of IL-10 on impaired IFN- $\gamma$ responses seen in MDR-TB. Depletion of $\mathrm{CD}^{+} \mathrm{CD} 25^{+} \mathrm{T}$ lymphocytes restored the capacity of MDR-TB T cells to respond to ESAT-6 in vitro, which suggests a potential role for $\mathrm{T}_{\text {reg }} / \mathrm{T}$ regulatory 1 cells in the pathogenesis of MDR-TB. Together, our results indicate that although the similarities in chronicity, NTM- and MDRTB-impaired antigenic responses involve different mechanisms.
\end{abstract}

Keywords: IL-10, immunosuppression, MDR-TB, NTM, regulatory T cells

\section{Introduction}

Tuberculosis (TB) is the second leading cause of death worldwide among infectious diseases. Despite the existence of effective multi-drug therapy, efforts to treat patients with active disease and to control the spread of TB are complicated by poor patient compliance, co-infection with human immunodeficiency virus (HIV) and the emergence of Mycobacterium tuberculosis (MTB)-resistant strains. Tubercular resistance to both isoniazid and rifampicin defines multi-drug-resistant TB (MDR-TB). In addition, the occurrence of extensive and totally drug-resistant MTB strains have been largely documented [1-3].

More recently, infection caused by non-tuberculous mycobacteria (NTM) has been recognized increasingly as an important cause of chronic pulmonary disease in patients with structural abnormalities of the lung, such as chronic obstructive pulmonary disease (COPD), cystic fibrosis and bronchiectasis [4]. NTM are environmental microorganisms classified as slow grower (SGM) or rapid grower mycobacteria (RGM). Interestingly, the prevalence of lung disease due to NTM in many countries exceeds that of MTB. Even though the pathogenesis of NTM infection is not completely understood, it is clear that both host and mycobacterial factors are involved [4-6].

Early secretory antigenic target (ESAT)-6 is an immunodominant region of difference (RD) 1 protein that has been demonstrated to be absent in all strains of M. bovis BCG [7] which confers both diagnostic and immunogenic potential 
to this molecule [8-10]. We have shown that the overall immune response to $M$. tuberculosis antigens is decreased in patients with MDR-TB [11-14]. Recent studies have shown poor antigen-specific induction of interleukin (IL)-2 and interferon (IFN) $-\gamma$ in TB patients with progressive disease. A T helper type 2 (Th2) type of response has been observed to occur during the advanced stages of $\mathrm{TB}$ marked by enhanced production of IL-4 and IL-10 and the expansion of regulatory $\mathrm{T}$ cells $\left(\mathrm{T}_{\text {reg }}\right)$, characterized by $\mathrm{CD} 4^{+} \mathrm{CD} 25^{\text {high }}$, forkhead box protein 3 (FoxP3) and CD39 expression [15]. $\mathrm{T}_{\text {regs }}$ interfere in a variety of pathophysiological disorders. In the periphery, adaptive $\mathrm{T}_{\mathrm{reg}}$ cells arise from $\mathrm{CD} 4^{+} \mathrm{T}$ cells following immune activation, including $\mathrm{T}$ helper type 3 (Th3) [transforming growth factor (TGF)- $\beta$ ] and T regulatory 1 cells (Tr1) (IL-10) cells [16].

Studies have showed that the number of $\mathrm{T}_{\text {reg }}$ cells increases in the blood or at the site of infection in active TB patients $[17,18]$, and that the frequency of $\mathrm{T}_{\text {regs }}$ in pleural fluid correlates inversely with the local specific immune response. MDR-TB patients had an increased proportion of circulating $\mathrm{T}_{\text {reg }}$ cells, and these cells expanded in vitro independently of the M. tuberculosis strain used [12]. In addition, the fact that NTM infection in IFN- $\gamma$ knock-out mice leads to progressive pulmonary disease and accumulation of $\mathrm{CD}^{+} \mathrm{FoxP}^{+}$regulatory $\mathrm{T}$ cells in the lungs suggests that $\mathrm{T}_{\text {reg }}$ cells may influence the progression of mycobacterial disease [19].

In this study we aimed to investigate the cytokine response and participation of $\mathrm{T}_{\text {reg }}$ cells in pulmonary mycobacterial disease. We compared ex vivo and antigen-driven induction of $\mathrm{T}_{\text {reg }}$ cells in MDR-TB and in patients with NTM infection. Enhanced serum levels of IL-10 and cytokine production in vitro was detected in MDR-TB patients, whereas enhanced systemic TGF- $\beta$ levels were detected in the NTM patient population. Our results demonstrate that $\mathrm{T}_{\text {reg }}$ cells occurred mainly in MDR-TB and these cells seem to impair IFN- $\gamma$ production in response to ESAT-6.

\section{Materials and methods}

\section{Study subjects}

Patients referred from the Ambulatory Service of the Health Unit, Reference Centre for Tuberculosis (Fiocruz) and from the District Hospital Raphael de Paula e Souza, Rio de Janeiro, Brazil, were enrolled into the study. Blood from healthy controls ( $\mathrm{HC}, n=18$ ) was obtained from the Hemotherapy Unit, Clementino Fraga Filho Hospital, Federal University of Rio de Janeiro. The study was approved by the Research Ethics Committee of the Oswaldo Cruz Institute, IOC, Fiocruz. The study was approved by the Ethical Research Committee, Oswaldo Cruz Institute, IOC, Fiocruz. All individuals provided written informed consent and experiments were performed as described. Criteria for diagnosis of MDR-TB comprised evidence of positive culture isolates resistant to at least isoniazid (INH) and rifampicin (RMP) and to any other specific anti-TB drug from standardized administration regimens, established according to Lowenstein Jensen and MGIT, with proportional methods for sensitivity patterns. All MDR cases had pulmonary disease and patients with concurrent infectious diseases or non-infectious conditions, such as cancer, diabetes or steroid therapy were excluded. For patients with nonresistant tuberculosis (NR-TB), at least one positive smear or positive culture and suggestive clinical symptoms of pulmonary disease were considered. Patients with lung disease defined as NTM had their clinical mycobacterial isolates characterized by analysis of phenotypic characteristics, growth rate and pigment production and by polymerase chain reaction (PCR)-restriction enzyme analysis of the hsp65 gene (PRA-hsp65) [20]. All patients tested negative for HIV [enzyme-linked immunosorbent assay (ELISA)] and were consequently treated with regimens in accordance with the Brazilian Ministry of Health guidelines. The ages, gender, duration of treatment and characterization of mycobacterial isolates are described in Table 1.

\section{Cell preparation and stimulation}

Peripheral blood mononuclear cells (PBMC) were isolated from heparinized venous blood under endotoxin-free conditions using Ficoll-Hypaque (Pharmacia Fine Chemicals, Piscataway, NJ, USA) density centrifugation. PBMC $\left(10^{6}\right.$ cells $\left./ \mathrm{ml}\right)$ were suspended in RPMI-1640 medium supplemented with $100 \mathrm{U} / \mathrm{ml}$ penicillin, $100 \mu \mathrm{g} / \mathrm{ml}$ streptomycin, $2 \mathrm{mM}$ L-glutamine and 10\% fetal calf serum (FCS) (GiBco BRL, Gaithersburg, MD, USA). Cells were cultured subsequently in 96- or 24-well plates (Costar Corporation, Cambridge, MA, USA) at $37^{\circ} \mathrm{C}, 5 \% \mathrm{CO}_{2}$ and stimulated with 5 or $10 \mu \mathrm{g} / \mathrm{ml}$ ESAT-6 or phytohaemagglutinin $1 \%$ (PHA; Sigma Chemical Co., St Louis, MO, USA) for $72 \mathrm{~h}$ (for flow cytometry analysis) or 5 days (for measurement of protein release). In parallel experiments, rESAT-6 was used to stimulate cells in culture in the presence of human antiIL-10 or human anti-IL-10R $\alpha$ neutralizing antibodies (R\&D Systems Inc., Minneapolis, MN, USA) at $10 \mu \mathrm{g} / \mathrm{ml}$ or the respective isotype control.

\section{CD25 T cell depletion}

$\mathrm{CD}^{+} \mathrm{T}$ cells were isolated from PBMC by negative selection (Miltenyi Biotec, Bergisch Gladbach, Germany), then $\mathrm{CD} 4^{+} \mathrm{CD} 25^{+} \mathrm{T}$ cells were selected positively from $\mathrm{CD} 4^{+}$ $\mathrm{T}$ cells using a human $\mathrm{CD} 4^{+} \mathrm{CD} 25^{+} \mathrm{T}_{\text {reg }}$ isolation kit, according to the manufacturer's instructions (Miltenyi Biotec). Approximately $90 \%$ of $\mathrm{T}_{\text {regs }}$ were eliminated after depletion, as determined by flow cytometry analysis. The $\mathrm{CD}^{-}$ and $\mathrm{CD} 4^{+} \mathrm{CD} 25^{-}$cell fractions were pooled and used as $\mathrm{T}_{\text {reg }}$-depleted PBMC. 
Table 1. Clinical and treatment features of patients with pulmonary mycobacterial disease.

\begin{tabular}{|c|c|c|c|c|c|}
\hline \multirow[b]{2}{*}{ Variable } & \multirow[b]{2}{*}{ Category } & \multicolumn{3}{|c|}{ Patient groups } & \multirow[b]{2}{*}{ Total } \\
\hline & & NR-TB & MDR & NTM & \\
\hline \multirow[t]{2}{*}{ Sex } & Male & $58(42 \cdot 0)$ & $60(43 \cdot 5)$ & $20(14 \cdot 5)$ & $138(100)$ \\
\hline & Female & $27(38 \cdot 0)$ & $34(47 \cdot 9)$ & $10(14 \cdot 1)$ & $71(100)$ \\
\hline Median age, years (s.d.) & & $32(13 \cdot 8)$ & $38(11 \cdot 3)$ & $49(13 \cdot 6)$ & $40(13 \cdot 7)$ \\
\hline Median number of drugs (s.d.) & & $3(0 \cdot 1)^{*}$ & $4(0 \cdot 6)^{\dagger}$ & $3(0 \cdot 7)^{\ddagger}$ & $3(0 \cdot 8)$ \\
\hline Median disease duration, days (s.d.) & & $109(101 \cdot 6)$ & $371(612 \cdot 8)^{\psi}$ & $630(1149 \cdot 6)^{\#}$ & $384(889)$ \\
\hline \multirow[t]{8}{*}{ Pathogen } & M. tuberculosis & $85(47 \cdot 5)$ & $94(52 \cdot 5)$ & - & $179(100)$ \\
\hline & M. abscessus & - & - & $6(100)$ & $6(100)$ \\
\hline & M. kansasii & - & - & $6(100)$ & $6(100)$ \\
\hline & M. avium & - & - & $5(100)$ & $5(100)$ \\
\hline & M. fortuitum & - & - & $4(100)$ & $4(100)$ \\
\hline & M. intracelulare & - & - & $3(100)$ & $3(100)$ \\
\hline & M. asiaticum & - & - & $1(100)$ & $1(100)$ \\
\hline & Ign & - & - & $4(100)$ & $4(100)$ \\
\hline \multirow[t]{3}{*}{ Cavitation } & Yes & $17(22 \cdot 7)$ & $35(46 \cdot 7)$ & $23(30 \cdot 6)$ & $75(100)$ \\
\hline & No & $45(43 \cdot 7)$ & $51(49 \cdot 5)$ & $7(6 \cdot 8)$ & $103(100)$ \\
\hline & Ign & $23(74 \cdot 2)$ & $8(25 \cdot 8)$ & 0 & $31(100)$ \\
\hline
\end{tabular}

Most important drug regimen: ${ }^{*}$ isoniazid $(\mathrm{H})+$ rifampicin $(\mathrm{R})+$ pyrazinamide $(\mathrm{PZ}), 2$ months and $\mathrm{H}+\mathrm{R}, 4$ months; ${ }^{\dagger}$ amikacin $(\mathrm{AM})+$ ethambutol(E) + ofloxacin $(\mathrm{OFX})+$ terizidone $(\mathrm{TZ})$; ${ }^{\ddagger}$ clarithromycin $(\mathrm{CLA})+\mathrm{E}+\mathrm{TZ}$ and $\mathrm{E}+\mathrm{H}+\mathrm{R}$. ${ }^{\psi} P<0 \cdot 05$ in relation to active non-resistant tuberculosis (NR-TB) and non-tuberculous mycobacteria (NTM) groups; ${ }^{\#} P<0 \cdot 05$ in relation to NR-TB and multi-drug-resistant TB $(\mathrm{MDR}-\mathrm{TB})$. Ign = data could not be determined. Median (s.d.): median (standard deviation).

\section{Functional in vitro $\mathrm{T}_{\text {reg }}$ cell assays}

$\mathrm{CD} 4^{+} \mathrm{T}$ cells were isolated from PBMC by negative selection (Miltenyi Biotec). Cells were sorted further using antiCD25-phycoerythrin (PE) and anti-PE magnetic beads (Miltenyi Biotec). The purity of isolated $\mathrm{T} \mathrm{CD} 4^{+} \mathrm{CD} 25^{+}$and $\mathrm{T} \mathrm{CD} 4^{+} \mathrm{CD} 25^{-}$cells was $>90 \%$. $\mathrm{T}_{\text {reg }}$ cells were added at different ratios to $\mathrm{T} \mathrm{CD} 4^{+} \mathrm{CD} 25^{-}$responder cells $\left(5 \times 10^{4} /\right.$ well $)$ that had been isolated from either HC, NR-TB or MDR-TB patients. Cells were then stimulated with ESAT-6 $(5 \mu \mathrm{g} / \mathrm{ml})$ in the presence of mitomycin-treated $(25 \mu \mathrm{g} / \mathrm{ml})$ PMBC (5 $\times 10^{4}$ cells) obtained from the same donor. After 5 days, IFN- $\gamma$ levels were evaluated by ELISA and compared to levels in unstimulated cells.

\section{Cytokine measurement}

Serum samples were collected and stored at $-20^{\circ} \mathrm{C}$ until use. Cell culture supernatants and serum samples were assayed for cytokine production (IL-10, TGF- $\beta$ and IFN- $\gamma$ ) by ELISA processed according to the manufacturer's protocol (R\&D Systems).

\section{Flow cytometric analysis of cell surface markers and intracellular staining}

Ex vivo or cells stimulated for 3 days with ESAT-6 $(5 \mu \mathrm{g} / \mathrm{ml})$ were washed twice with phosphate-buffered saline (PBS) containing $0 \cdot 1 \%$ bovine serum albumin (BSA) and $0 \cdot 05 \%$ sodium azide. Cells were incubated with antibodies at $4^{\circ} \mathrm{C}$ in the dark for $20 \mathrm{~min}$. Cells were washed twice and fixed with $0.5 \%$ paraformaldehyde prior to acquisition. Intracellular cytokines were detected through the use of brefeldin A $(10 \mu \mathrm{g} / \mathrm{ml}$; Sigma-Aldrich) added for the last $5 \mathrm{~h}$ of culture. Cells were washed and fixed in fixation/permeabilization buffer (eBiosciences, San Diego, CA, USA), followed by permeabilization and staining for intracellular cytokines and molecules. Lymphocytes were gated based on forward- and side-scatter profiles. Flow cytometry was performed using Cyan (Dako Cytomation, Carpinteria, CA, USA) and analysed using Summit software (Dako Cytomation).

\section{Statistical analysis}

The EpiData and Statistical Package for the Social Sciences (SPSS Inc., Chicago, IL, USA) applications were used for demographic and clinical data entry and analysis, respectively. A statistical analysis was performed by descriptive analysis with numerical variables expressed as the median [standard deviation (s.d.)]. The Kolmogorov-Smirnov test was used to test the sample distribution. Statistical significance of the results was determined with GraphPad Prism version 5.0 (GraphPad Software, San Diego, CA, USA). Results are reported as median \pm range in non-parametric data or mean \pm standard error of the mean (s.e.m.) for parametric data. Data for patients in comparison to controls were analysed using the Kruskal-Wallis (with Dunn's post-test) or analysis of variance (ANOvA) test (with Tukey's post-test) whenever appropriate. The statistical significance level adopted was $P<0 \cdot 05$. 
Table 2. Frequencies of lymphocyte immunophenotypes in peripheral blood mononuclear cells.

\begin{tabular}{|c|c|c|c|c|c|c|c|c|c|c|c|c|c|}
\hline \multirow{2}{*}{\multicolumn{2}{|c|}{$\begin{array}{l}\text { Phenotype } \\
\text { PBMC samples }\end{array}$}} & \multicolumn{3}{|c|}{ NR-TB } & \multicolumn{3}{|c|}{ MDR } & \multicolumn{3}{|c|}{ NTM } & \multicolumn{3}{|c|}{$\mathrm{HC}$} \\
\hline & & $\mathrm{N}$ & M & IQR & $\mathrm{N}$ & M & IQR & $\mathrm{N}$ & M & IQR & $\mathrm{N}$ & M & IQR \\
\hline $\mathrm{CD}^{+} \mathrm{CD}^{+}$ & $\%$ of all & 10 & $46 \cdot 55$ & $35 \cdot 8-47 \cdot 3$ & 14 & $46 \cdot 4$ & $18 \cdot 3-66 \cdot 57$ & 12 & 41.90 & $38 \cdot 6-43 \cdot 1$ & 15 & 31 & $28 \cdot 7-35 \cdot 5$ \\
\hline $\mathrm{CD}^{+} \mathrm{CD}^{+}$ & $\begin{array}{l}\text { PBMC } \\
\text { lymphocytes }\end{array}$ & 10 & $6 \cdot 35$ & $3 \cdot 6-7 \cdot 0$ & 14 & $22 \cdot 7$ & $3 \cdot 7-29 \cdot 7$ & 12 & $15 \cdot 7$ & $13 \cdot 9-16 \cdot 5$ & 15 & $8 \cdot 1$ & $5-13 \cdot 1$ \\
\hline $\mathrm{CD}^{+} \mathrm{CD} 69^{+}$ & Proportion of & 10 & 0.047 & $0 \cdot 013-0 \cdot 34$ & 14 & $0 \cdot 063$ & $0 \cdot 032-0 \cdot 09$ & 12 & $0 \cdot 24^{\mathrm{a}}$ & $0 \cdot 18-0 \cdot 3$ & 15 & $0 \cdot 021$ & $0 \cdot 009-0 \cdot 057$ \\
\hline $\mathrm{CD}^{+}{ }^{+} \mathrm{CD} 25^{+}$ & cells/total & 10 & $0 \cdot 009$ & $0 \cdot 002-0 \cdot 38$ & 14 & $0 \cdot 17$ & $0 \cdot 059-0 \cdot 18$ & 12 & $0 \cdot 4$ & $0 \cdot 33-0 \cdot 44$ & 15 & $0 \cdot 010$ & $0.004-0.099$ \\
\hline $\mathrm{CD}^{+} \mathrm{IFN}^{+}$ & $\mathrm{CD} 4 \mathrm{~T}$ cells & 10 & $0 \cdot 021$ & $0 \cdot 009-0 \cdot 31$ & 14 & $0 \cdot 011$ & $0 \cdot 008-0 \cdot 07$ & 12 & $0 \cdot 12$ & $0 \cdot 09-0 \cdot 14$ & 15 & $0 \cdot 058$ & $0 \cdot 051-0 \cdot 18$ \\
\hline $\mathrm{CD}^{+} \mathrm{TNF}^{+}$ & & 10 & $0 \cdot 031$ & $0 \cdot 012-0.33$ & 14 & $0 \cdot 11$ & $0 \cdot 09-0 \cdot 17$ & 12 & $0 \cdot 14$ & $0 \cdot 12-0 \cdot 17$ & 15 & $0 \cdot 09$ & $0 \cdot 036-0 \cdot 22$ \\
\hline $\mathrm{CD}^{+} \mathrm{CD} 9^{+}$ & Proportion of & 10 & $0 \cdot 203$ & $0 \cdot 1-0 \cdot 66$ & 14 & $0 \cdot 38$ & $0 \cdot 014-0.57$ & 12 & $0 \cdot 84^{\mathrm{a}, \mathrm{b}}$ & $0 \cdot 74-0 \cdot 93$ & 15 & $0 \cdot 129$ & $0 \cdot 033-0 \cdot 27$ \\
\hline $\mathrm{CD}^{+} \mathrm{CD} 25^{+}$ & cells/total & 10 & $0 \cdot 12$ & $0 \cdot 014-1 \cdot 44$ & 14 & $0 \cdot 015$ & $0 \cdot 012-0.06$ & 12 & $0 \cdot 66^{\mathrm{a}}$ & $0 \cdot 65-0 \cdot 72$ & 15 & $0 \cdot 025$ & $0 \cdot 01-0 \cdot 034$ \\
\hline $\mathrm{CD}^{+} \mathrm{IFN}^{+}$ & CD8 T cells & 10 & $0 \cdot 15$ & $0 \cdot 005-0 \cdot 35$ & 14 & $0 \cdot 056^{\mathrm{a}}$ & $0 \cdot 009-0 \cdot 13$ & 12 & $0 \cdot 15$ & $0 \cdot 11-0 \cdot 19$ & 15 & $0 \cdot 11$ & $0 \cdot 04-0 \cdot 27$ \\
\hline $\mathrm{CD}^{+} \mathrm{TNF}^{+}$ & & 10 & $0 \cdot 21$ & $0 \cdot 07-0 \cdot 43$ & 14 & $0 \cdot 106$ & $0.098-0.55$ & 12 & $0 \cdot 2$ & $0 \cdot 09-0 \cdot 34$ & 15 & $0 \cdot 215$ & $0 \cdot 16-0 \cdot 35$ \\
\hline
\end{tabular}

${ }^{\mathrm{a}} \mathrm{P}<0.05$ in relation to healthy controls (HC) group. ${ }^{\mathrm{b}} \mathrm{P}<0.05$ in relation to multi-drug-resistant TB (MDR-TB) group. IQR: interquartile range; M: median; NTM: non-tuberculous mycobacteria; NR-TB: active non-resistant tuberculosis; PBMC: peripheral blood mononuclear cells.

\section{Results}

\section{Analysis of ex vivo T cell phenotype in recruited patients}

Between 2004 and 2012, 85 NR-TB, 94 MDR-TB and 30 NTM patients were recruited for this study. Blood samples of all participants were taken for immunological analysis. PBMCs were used for fluorescence activated cell sorter (FACS) analysis and cell culture. Ex vivo (0 h) FACS analysis on PBMC from 10 NR-TB, 14 MDR-TB, 12 NTM and 15 healthy controls (HC) were performed (Table 2). No significant differences were observed when comparing the percentages of $\mathrm{CD}^{+} \mathrm{CD}^{+}$and $\mathrm{CD}^{+} \mathrm{CD}^{+}$cells in the different groups (Table 2). Analysis of activation markers on $\mathrm{CD}^{+}$ population revealed that NTM patients have an increased frequency of $\mathrm{CD}^{+} \mathrm{CD}^{+} 9^{+}$per total $\mathrm{CD} 4^{+} \mathrm{T}$ cells $[0 \cdot 24(0 \cdot 18-$ $0 \cdot 3)]$ in comparison to HC [0.021 (0.009-0.057)] $(P<0 \cdot 05)$. No differences were detected in $\mathrm{CD} 4^{+} \mathrm{IFN}-\gamma^{+}$and $\mathrm{CD}^{+} /$tumour necrosis factor $(\mathrm{TNF})^{+}$cells in the groups tested. However, $\mathrm{CD} 8^{+} \mathrm{IFN}-\gamma^{+}$cells were decreased in MDR-TB when compared to HC [0.056 (0.009-0.13) versus $0 \cdot 11(0 \cdot 04-0 \cdot 27)$, respectively, $P<0 \cdot 05]$.
Analysis of activation markers on $\mathrm{CD}^{+}$population revealed that both $\mathrm{CD}^{+} \mathrm{CD} 25^{+}$and $\mathrm{CD} 8^{+} \mathrm{CD} 69^{+}$frequencies were higher in NTM when compared to $\mathrm{HC}$, and $\mathrm{CD}^{+} \mathrm{CD} 9^{+}$frequency was also significantly higher in NTM when compared to MDR-TB [0.84 $(0.74-0.93)$ in NTM versus $0 \cdot 11(0 \cdot 09-0 \cdot 17)$ in MDR-TB, $P<0 \cdot 05$ ].

In addition, we evaluated ex vivo the frequencies of $\mathrm{CD}^{+} \mathrm{CD} 25^{+} \mathrm{FoxP}^{+}$and $\mathrm{CD} 4^{+} \mathrm{CD} 25^{+} \mathrm{CD} 127^{-} \mathrm{T}$ cells in total $\mathrm{CD}^{+} \mathrm{T}$ cells from patients' PBMCs. As observed in Fig. 1a,b, both MDR-TB and NTM patients showed increased frequencies of $\mathrm{T}_{\text {reg }}$ cells when compared to the NR-TB group.

\section{Serum IL-10 and TGF- $\beta$ levels are increased in patients with mycobacterial disease}

TGF- $\beta$ and IL-10 are well-recognized regulatory cytokines that can modulate inflammatory responses and $\mathrm{T}$ cell function. Evaluation of these cytokines in serum samples from patients with TB or NTM infection showed increased IL-10 levels in MDR-TB when compared to HC, NTM and NR-TB (Fig. 2a; $P<0.05$ ); conversely, serum TGF- $\beta$ levels were enhanced significantly $(P=0.006)$ in NTM patients
Fig. 1. Frequency of regulatory cells in peripheral blood from pulmonary patients. The proportion of $\mathrm{CD}^{+} \mathrm{T}$ cells expressing (a)

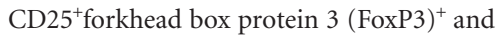
(b) $\mathrm{CD} 25^{+} \mathrm{CD} 127^{-}$in active non-resistant tuberculosis (NR-TB), $n=10$ ); multi-drugresistant TB (MDR-TB) $(n=14)$, nontuberculous mycobacteria (NTM) $(n=12)$ and healthy controls (HC) $(n=15)$. The bars represent the medians \pm range. ${ }^{\star} P<0 \cdot 05$; ${ }^{*} P<0 \cdot 01$.
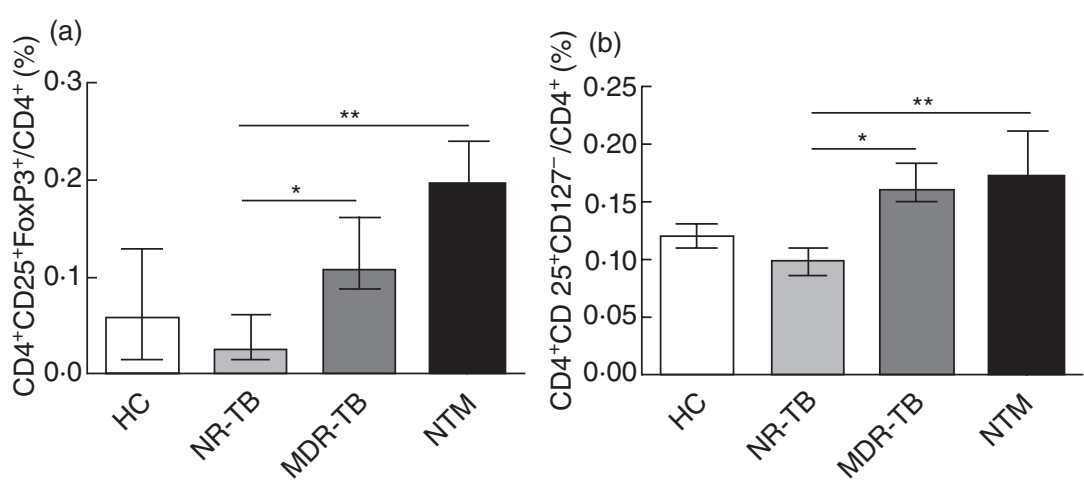
(a)

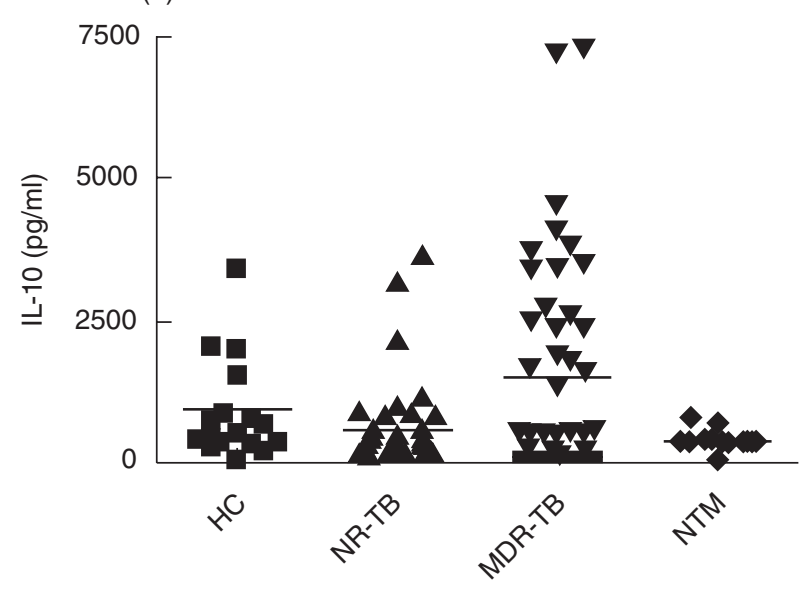

(b)

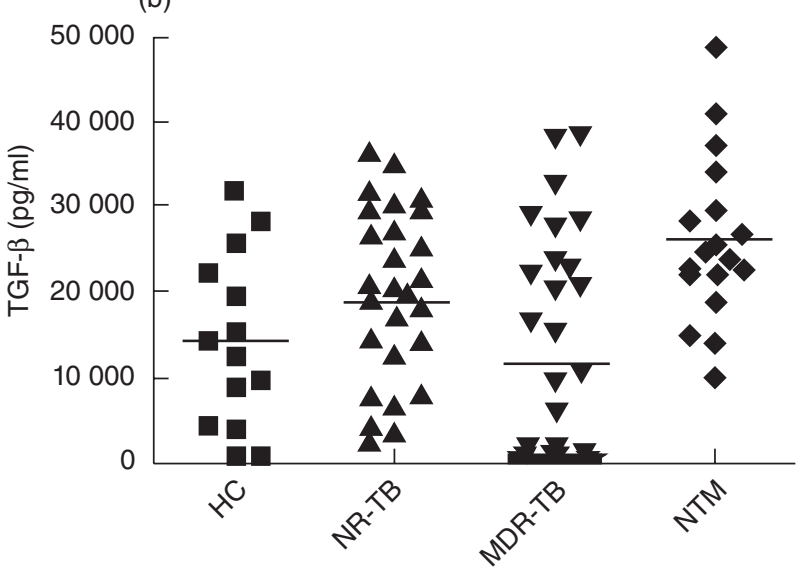

Fig. 2. Cytokine levels in serum from tuberculosis (TB) and non-tuberculous mycobacteria (NTM) patients. (a) Interleukin (IL)-10 was detected by enzyme-linked immunosorbent assay (ELISA) in serum samples obtained from healthy controls (HC, $n=17$ ), untreated non-resistant TB (NT, $n=44)$, multi-drug-resistant TB (MDR-TB) $(n=46)$ and NTM patients $(n=18) .{ }^{*} P<0 \cdot 05$ when compared to healthy controls (HC), active non-resistant tuberculosis (NR-TB)and NTM groups; (b) For transforming growth factor (TGF) $-\beta$, total individuals assayed per group were $14 \mathrm{HC}, 30 \mathrm{NR}-\mathrm{TB}$, 32 MDR-TB and 18 NTM patients. ${ }^{*} P<0.05$ when compared to HC, NR-TB and MDT-TB groups. Each symbol represents one single individual. Horizontal bars denote mean cytokine levels in each group.

(Fig. 2b). Analysis of serum cytokine levels comparing NTM patients infected with SGM or RGM revealed no differences in IL-10 values (not shown), whereas an increase in TGF- $\beta(P=0.049)$ in the RGM- versus SGMinfected patients was detected (31232 44890 versus $23096 \pm 2611 \mathrm{pg} / \mathrm{ml}$, respectively). We did not find any correlation between IL-10 levels and disease duration; however, we verified a positive correlation of TGF- $\beta$ levels in NTM patients with longer disease duration in days (not shown).
Regulatory T cells are increased in ESAT-6-stimulated cells from MDR-TB patients

M. tuberculosis-induced IFN- $\gamma$ production was assayed in response to ESAT-6 in vitro. As expected, cells from NTM patients did not release IFN- $\gamma$ following cell stimulation with ESAT-6 (not shown). We also confirmed our previous data [21] showing that MDR-TB patients have impaired responses to ESAT-6 $(132 \cdot 8 \pm 35 \cdot 3 \mathrm{pg} / \mathrm{ml}, n=50)$ when compared to NR-TB (untreated patients, $1143 \pm 336 \mathrm{pg} / \mathrm{ml}$; $P=0.0002, n=29 ;$ or treated TB, $1496 \pm 479, n=14$; $P=0 \cdot 0001)$.

To determine the phenotype responsible for IFN- $\gamma$ secretion, we evaluated the percentage of $\mathrm{CD}^{+} \mathrm{CD}^{+}$and $\mathrm{CD}^{+}{ }^{+} \mathrm{CD}^{+} \mathrm{T}$ cells in the ESAT-6-stimulated cultures. No significant changes were observed in $\mathrm{CD}^{+} \mathrm{CD}^{+}$frequencies between the different groups (Fig. 3a); however, in ESAT-6stimulated cultures, the frequency of $\mathrm{CD}^{+} \mathrm{CD} 4^{+}$cells were lower in NR-TB when compared to HC group (Fig. 3a). The frequency of $\mathrm{CD}^{+} \mathrm{CD}^{+}$cells in the NR-TB group was significantly higher than in $\mathrm{HC}$, but no significant changes were observed when compared with MDR-TB and NTM groups (Fig. 3b). Analysis of $\mathrm{CD} 4^{+} \mathrm{IFN}-\gamma^{+}$cells revealed that ESAT- 6 decreases the frequency of this population in MDR-TB-stimulated cells when compared with nonstimulated cells. The same was observed in purified protein derivative (PPD)-stimulated MDR-TB cells. In addition, higher $\mathrm{CD} 4^{+} \mathrm{IFN}-\gamma^{+}$frequencies were observed in ESAT-6stimulated NR-TB when compared with ESAT-6-stimulated MDR-TB cells (Fig. 3c). No significant differences were observed in $\mathrm{CD} 8^{+} \mathrm{IFN}-\gamma^{+}$frequencies in the different groups studied, or in cultures stimulated with PPD or ESAT-6 (Fig. 3d).

The stimulation of cells with ESAT- 6 led to an enhanced frequency of $\mathrm{CD}^{+} \mathrm{CD} 25^{+} \mathrm{FoxP} 3^{+}$cells in MDR-TB when compared to non-stimulated cells. The capacity of ESAT-6 increase $\mathrm{CD}^{+} \mathrm{CD} 25^{+} \mathrm{FoxP}^{+}$in vitro was observed in MDR-TB cells, but not in the other groups studied (not shown). These cells were also CTLA- $4^{+}$and CD127 $7^{\text {low }}$ ( $90 \%)$ (not shown). Both PPD and ESAT-6 were able to increase $\mathrm{CD}^{+} \mathrm{CD} 25^{+} \mathrm{FoxP}^{+}$and $\mathrm{CD} 4^{+} \mathrm{CD} 25^{+} \mathrm{CD} 127^{-}$frequencies in MDR-TB when compared to non-stimulated cells; however, only ESAT-6 was able to increase significantly the frequency of $\mathrm{CD} 4^{+} \mathrm{CD} 25^{+} \mathrm{IL}-10^{+}$cells (Fig. $4 \mathrm{a}-\mathrm{c}$ ), which suggests that both $\mathrm{T}_{\text {reg }}$ and $\operatorname{Tr} 1$ cells may be involved in the impaired IFN $-\gamma$ responses following ESAT- 6 stimulation in MDR-TB patient cells.

Enhanced IL-10 is detected in stimulated cultures and modulates the rate of $\mathrm{T}_{\text {reg }}$ cells

We then investigated the secretion of IL-10 in the supernatants from ESAT-6 stimulated cultures. In agreement with the enhanced IL-10 levels detected in the serum samples, cells from MDR-TB showed increased IL-10 production 
Fig. 3. Interferon (IFN) $-\gamma$ expression in stimulated $\mathrm{CD} 4^{+}$and $\mathrm{CD} 8^{+} \mathrm{T}$ cells from the different groups tested. The proportion of $\mathrm{CD}^{+} \mathrm{T}$ cells (a) or $\mathrm{CD} 8^{+} \mathrm{T}$ cells (b) in purified protein derivative (PPD) or early secretory antigenic target (ESAT)-6-stimulated cultures is presented. $\mathrm{CD}^{+}$and $\mathrm{CD} 8^{+} \mathrm{T}$ cells co-expressing IFN- $\gamma(\mathrm{C}-\mathrm{D})$ in healthy controls (HC) $(n=15)$, active non-resistant tuberculosis (NR-TB) $(n=17)$, multi-drug-resistant TB (MDR-TB) $(n=10)$, non-tuberculous mycobacteria (NTM) $(n=19)$. The bars represent the medians \pm range. ${ }^{\star} P<0 \cdot 05 ; \# P<0 \cdot 05$ in relation to NS cultures from MDR-TB. (a)

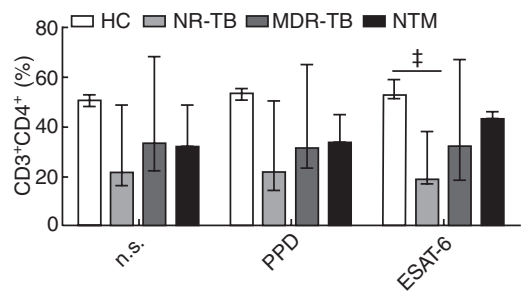

(c)

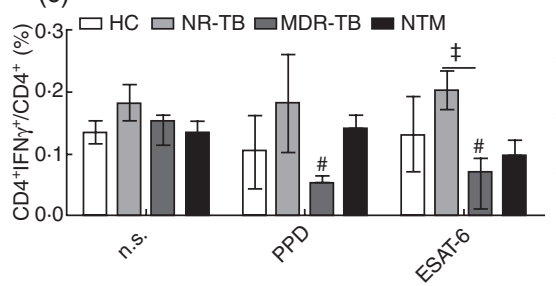

(b)

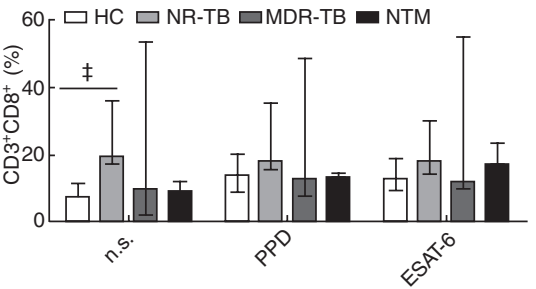

(d)

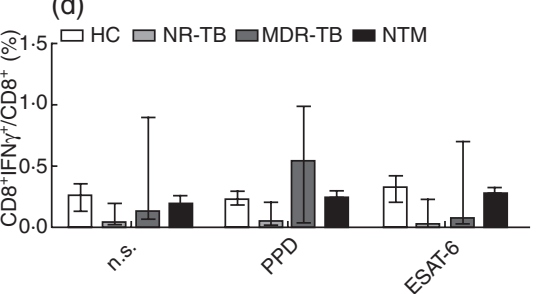

when compared to NR-TB, NTM and HC (Fig. 4d). Following ESAT-6 stimulation there was an increase in the frequency of $\mathrm{IL}-10^{+}$cells in $\mathrm{CD}^{+} \mathrm{T}$ cells from MDR-TB patients, but not in $\mathrm{CD}^{+} \mathrm{T}$ cells (data not shown). To establish further the role of IL-10 in the impaired response observed in MDR patients, we neutralized IL-10 or IL-10R $\alpha$ in the cultures. Following the blockade of IL-10 or IL-10R $\alpha$, lower rates of $\mathrm{T}_{\text {reg }}$ cells were observed in ESAT-6-stimulated cultures (Fig. 5); however, it did not restore fully the capacity of MDR-TB cells to respond to ESAT- 6 in vitro, which suggest that this is not the only mechanism of regulation.

\section{$\mathrm{T}_{\text {reg }}$ depletion restores IFN- $\gamma$ response in ESAT-6-stimulated MDR-TB cultures}

Because activated cells express FoxP3 transiently, we investigated the suppressive activity of $\mathrm{CD} 4^{+} \mathrm{CD} 25^{+} \mathrm{T}$ cells from MDR-TB patients. As observed in Fig. $6 \mathrm{a}$, the addition of ESAT-6 decreased the suppressive activity of $\mathrm{CD} 4{ }^{+} \mathrm{CD} 25^{+}$ $\mathrm{T}$ cells in both NR-TB and HC groups, with no influence on the suppressive effect of MDR-TB $\mathrm{T}_{\text {reg }}$ cells. At a ratio of $10: 5$ of $\mathrm{CD} 4^{+} \mathrm{CD} 25^{-} / \mathrm{CD} 4^{+} \mathrm{CD} 25^{+}$cells, it was possible to observe that ESAT-6 decreased IFN- $\gamma$ production in the
Fig. 4. Frequency of regulatory cells in early secretory antigenic target (ESAT)-6-stimulated multi-drug-resistant TB (MDR-TB) patient cells. The proportion of $\mathrm{CD}^{+} \mathrm{T}$ cells expressing $\mathrm{CD} 25^{+}$forkhead box protein 3 (FoxP3) ${ }^{+}$(a), $\mathrm{CD} 25^{+} \mathrm{CD} 127^{-}(\mathrm{b})$ and $\mathrm{CD} 25^{+}$interleukin (IL) $-10^{+}$(c) were evaluated in purified protein derivative (PPD) or ESAT-6-stimulated cells from the MDR-TB group $(n=17)$ after 3 days of culture. ${ }^{\star} P<0 \cdot 05 ;{ }^{\star \star} P<0 \cdot 01 ;{ }^{* *} P<0 \cdot 001$.

(d) Levels of IL-10 were assessed by enzyme-linked immunosorbent assay (ELISA) following in vitro stimulation of peripheral blood mononuclear cells (PBMC) obtained from nine healthy controls (HC), 11 active non-resistant tuberculosis (NR-TB), 10 MDR-TB and eight non-tuberculous mycobacteria (NTM) patients with ESAT-6 $(10 \mu \mathrm{g} / \mathrm{ml})$. Values in the figure are mean IL-10 values ( \pm standard error of the mean). $\# P<0.05$ in relation to the other tested groups.
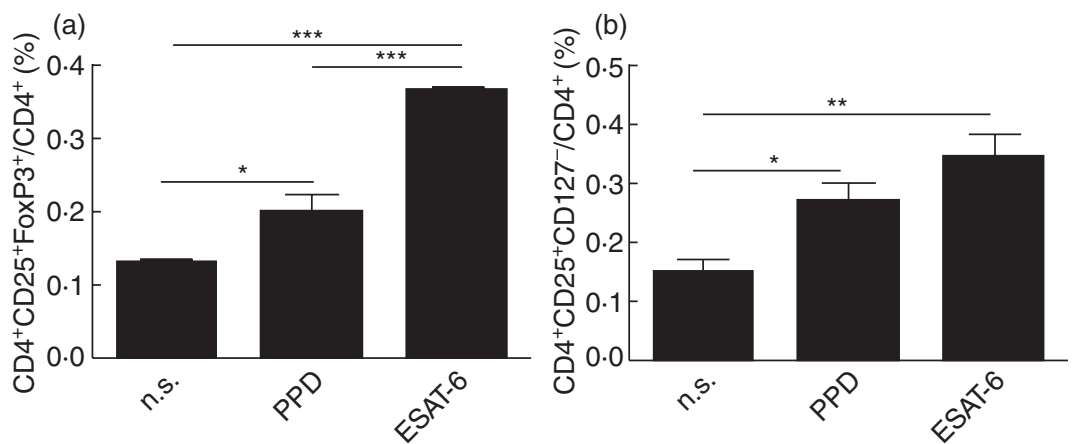

(c)

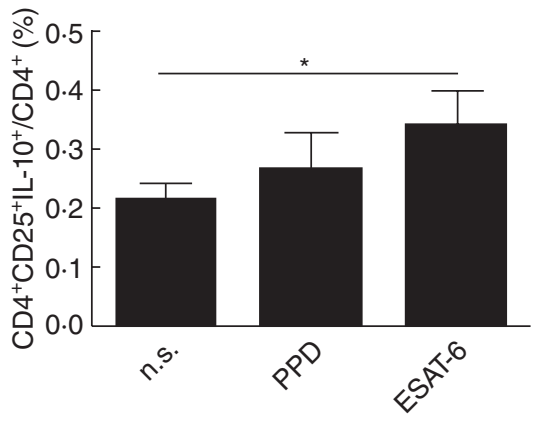

(d)

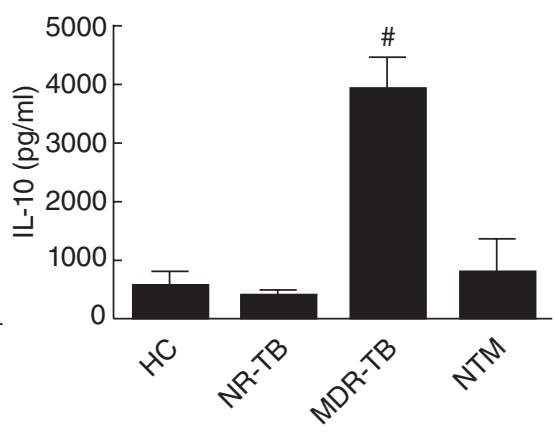




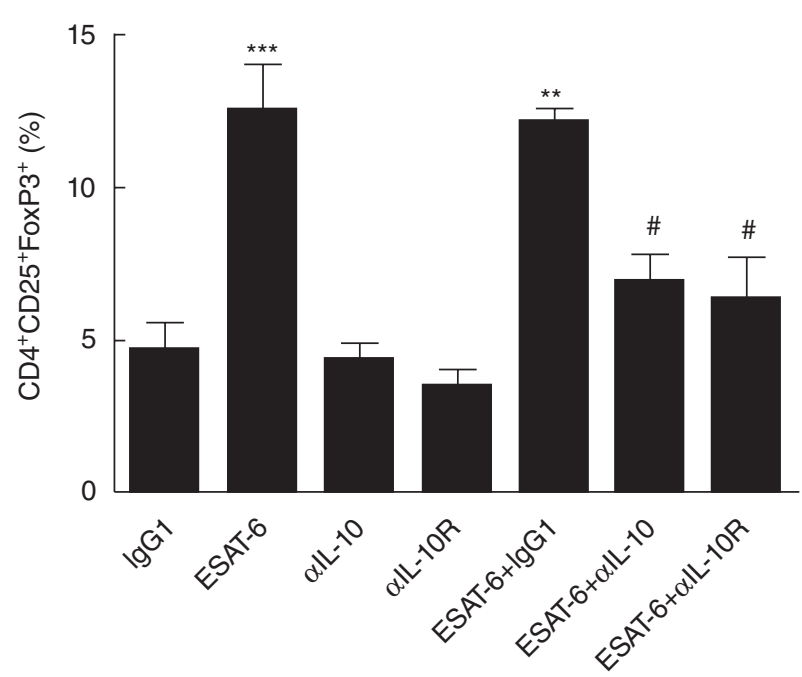

Fig. 5. Blockade of interleukin (IL)-10 partially abrogates the increase in regulatory $\mathrm{T}$ cell $\left(\mathrm{T}_{\text {reg }}\right)$ population. (a) Cells from multi-drug-resistant TB (MDR-TB) patients $(n=9)$ were incubated with early secretory antigenic target (ESAT)- 6 in the presence or absence of IL-10 monoclonal antibodies (mAb) or IL-10R $\alpha$ mAb for 3 days. After this period, the percentage of $\mathrm{CD} 4^{+} \mathrm{CD} 25^{+}$forkhead box protein 3 (FoxP3) $^{+} \mathrm{T}$ cells was evaluated by flow cytometry. Results are mean \pm standard error of the mean. ${ }^{\star} P<0 \cdot 05 ;{ }^{*} P<0 \cdot 01$; ${ }^{* * *} P<0.001$ in relation to immunoglobulin (Ig)G1, $\alpha$ IL-10 and $\alpha$ IL-10R $\alpha . \# P<0.05$ in relation to ESAT-6.

MDR-TB group (Fig. 6a). Together, these data suggest that in NR-TB $\mathrm{CD}_{4}{ }^{+} \mathrm{CD} 25^{+} \mathrm{T}$ cells may have an effector phenotype, whereas in MDR-TB patients, $\mathrm{CD} 4^{+} \mathrm{CD} 25^{+} \mathrm{T}$ cells were truly $\mathrm{T}_{\text {reg }}$ cells.

In order to determine whether $\mathrm{T}_{\text {regs }}$ may hinder an anti-TB immune response, $\mathrm{CD} 4^{+} \mathrm{CD} 25^{+} \mathrm{T}$ cells were depleted from MDR-TB patients' PBMC. In the patients analysed, $\mathrm{CD} 4^{+} \mathrm{CD} 25^{+}$-depleted $\mathrm{T}$ cells showed a significant increase in IFN- $\gamma$ response against ESAT- 6 in the two tested concentrations ( 5 and $10 \mu \mathrm{g} / \mathrm{ml}$ ). In contrast, MDR-TB cells in the presence of $\mathrm{T}_{\text {reg }}$ were unable to produce similar levels of IFN- $\gamma$ in response to ESAT-6 (Fig. 6b). In patients with NR-TB and HC, no significant effect of $\mathrm{CD}_{4}^{+} \mathrm{CD} 25^{+} \mathrm{T}$ cells was noted on IFN- $\gamma$ secretion induced by ESAT- 6 (not shown). Together, our data suggest that in MDR-TB, $\mathrm{T}_{\text {reg }}$ cells may lead to the impairment of the cell response to ESAT-6 by a mechanism that is partially dependent upon IL-10.

\section{Discussion}

The role of the various $\mathrm{T}$ cells in mycobacterial disease and their contribution to immunopathogenesis in disease progression has not been clarified. We found that the levels of blood $\mathrm{T}_{\text {reg }}$ were increased in both MDR-TB and NTM patients when compared with NR-TB patients. A recent paper has suggested that, in humans, prior exposure to
Mycobacterium antigens induces $\mathrm{CD} 44^{+} \mathrm{CD} 25^{\text {hi }} \mathrm{CD} 39^{+}$regulatory cells associated with a poorer Th17 response to a new tuberculosis vaccine currently in clinical trials [22]. Besides the capacity of modulating BCG responses, the prevalence of chronic lung disease due to NTM is increasing
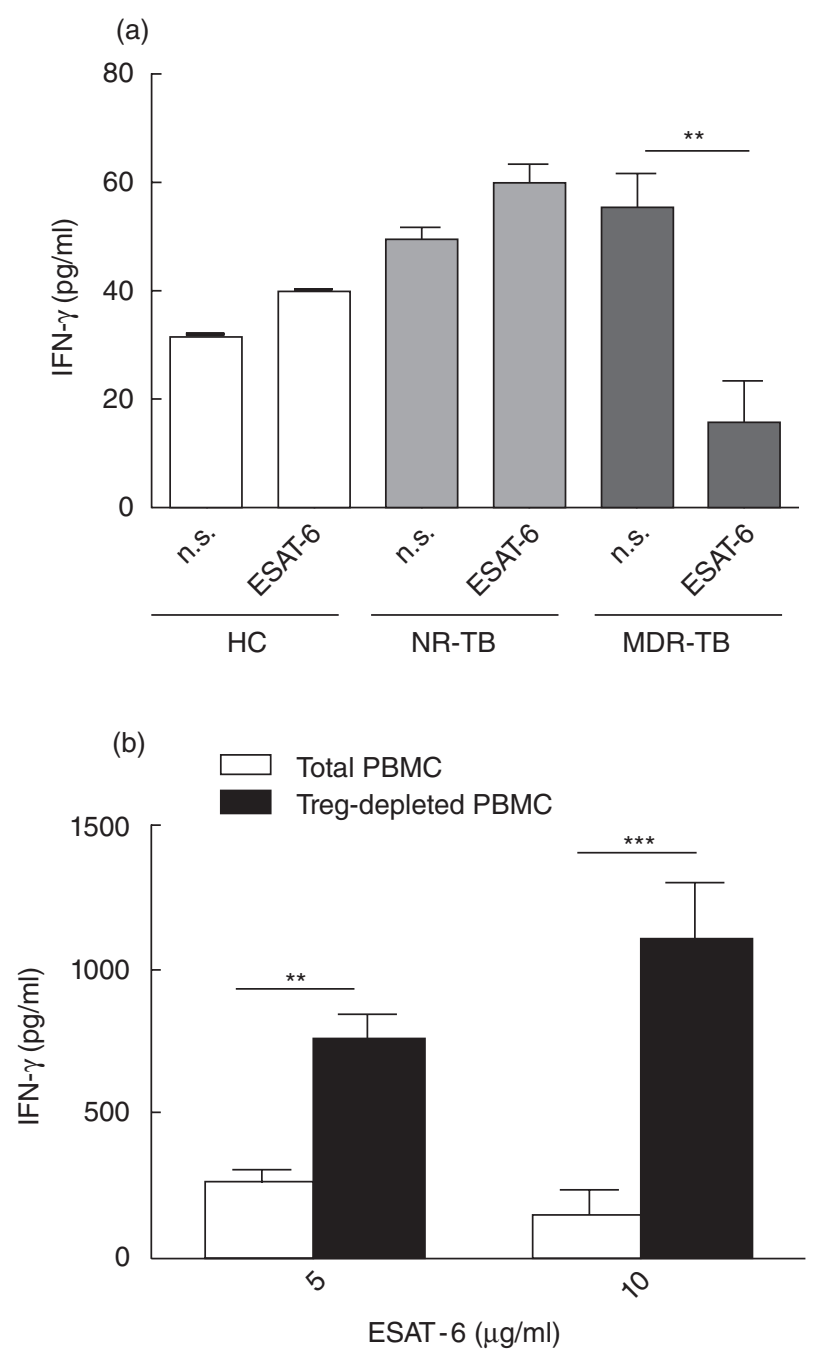

Fig. 6. Depletion of $\mathrm{CD} 4^{+} \mathrm{CD} 25^{+} \mathrm{T}$ cells [regulatory $\mathrm{T}$ cells $\left(\mathrm{T}_{\text {reg }}\right)$ ] from multi-drug-resistant TB (MDR-TB) patient peripheral blood mononuclear cells (PBMC) increases interferon (IFN) $-\gamma$ production in response to early secretory antigenic target (ESAT)-6. (a) $\mathrm{CD} 4^{+} \mathrm{CD} 25^{+}$ $\mathrm{T}$ cells were isolated and cultured at a $5: 10$ ratio with $\mathrm{CD} 4^{+} \mathrm{CD} 25^{-}$ $\mathrm{T}$ cells in the absence or presence of ESAT- $6(5 \mu \mathrm{g} / \mathrm{ml})$. IFN- $\gamma$ was evaluated in culture supernatants by enzyme-linked immunosorbent assay (ELISA) on day 5. Cells were stimulated with ESAT-6 $(5 \mu \mathrm{g} / \mathrm{ml})$. Data are mean \pm standard error of the mean (s.e.m.). ${ }^{* *} P<0 \cdot 01$. (b) $\mathrm{T}_{\text {reg }}$-depleted or -undepleted PBMC from MDR-TB patients were stimulated with anti-CD3 monoclonal antibodies $(\mathrm{mAb})(1 \mu \mathrm{g} / \mathrm{ml})$ and cultured in the presence or absence of indicated concentrations of ESAT-6 ( 5 or $10 \mu \mathrm{g} / \mathrm{ml}$ ). After 5 days, IFN- $\gamma$ production in the supernatants was evaluated using ELISA to compare PBMC with

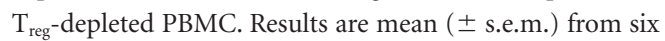
independent experiments. ${ }^{\star}$ Indicates significant enhancement of cytokine response $(P<0 \cdot 05)$. 
and therapeutic schemes against these NTM are poor; a greater understanding of host-immune responses to these organisms is needed.

There has been a concerted effort over the last few years to characterize specific $M$. tuberculosis molecules for inclusion into a novel TB vaccine and develop a more efficacious diagnostic test. The ESAT-6 molecule has been shown to have diagnostic potential $[23,24]$. The ESAT-6 gene is restricted largely to the tuberculosis complex, being absent in all bacillus Calmette-Guérin (BCG) strains and in environmental isolates, with the exception of M. kansasii, M. marinum and M. szulgai [25].

The specificity of blood tests for TB diagnosis was probably underestimated due to cross-reaction to NTM infection and the lack of a confirmatory test to diagnose latent TB infection [26-28]. Among the NTM patients, we had six patients who were infected with M. kansasii, but these patients did not respond to ESAT-6 after in vitro stimulation (not shown). Other studies have demonstrated that NTM patients present low IFN- $\gamma$ and TNF- $\alpha$ production to different antigens when compared to TB patients [29]. In patients with systemic suppression and primary immunodeficiency diseases it affects not only the Th1 cell compartment, but also Th2 and Th17 [6,30]. Although the number of NTM patients included in this study is low, the results deserve further investigation and may reinforce the discussion regarding the potential of ESAT- 6 as a diagnostic tool to detect active infection by drug-susceptible M. tuberculosis strains.

Previous studies have associated a persistent Th1 response to $\mathrm{TB}$ infection with the presence of cavitation in affected lungs from MDR-TB and NR-TB patients [31]. A total of 23 of the 30 enrolled NTM patients presented with pulmonary cavitation. Analysis of circulating TNF-secreting CD4 T cells demonstrated that the frequency of these cells was higher in individuals with cavitation (not shown).

Measuring serum cytokine levels can assess the systemic cytokine response in infected patients. In this study, we observed that MDR-TB patients have increased IL-10 serum levels when compared to $\mathrm{HC}$ or untreated NR-TB groups. In contrast to the observations of Deveci et al. [32], we did not observe increased IL-10 serum levels in NR-TB. Others have proposed that IL-10 plays a determinant role in the pathogenesis of tuberculosis based on the observation that moderate and advanced patients show higher IL-10 levels in comparison to patients with mild cases [33]. Another important regulatory cytokine, TGF- $\beta$, was detected previously at sites of M. tuberculosis infection and may undermine host immune responses during TB [34]. However, we did not observe significant differences in TGF- $\beta$ serum levels between TB patients and controls.

We have demonstrated for the first time that NTM patients have increased TGF- $\beta$ serum levels when compared to $\mathrm{HC}$ and TB patients. As NTM patients have a longer duration of treatment than do patients with TB (Table 1), we postulate that increased TGF- $\beta$ production in this group may be result of the chronicity of lung disease caused by these atypical mycobacteria. These data should be confirmed in larger cohorts of NTM patients with pulmonary disease. We did not observe increased IFN- $\gamma$ serum levels in NTM patients (not shown); however, previous work has demonstrated increased CXCL-10 levels in plasma from NTM patients when compared to HC [35].

MDR-TB strains $\mathrm{M}$ and $\mathrm{Ra}$ were shown to be weak inducers of IFN- $\gamma$, and in vitro expansion of $\mathrm{T}_{\text {reg }}$ cells in PBMC from TB patients was demonstrated to be M. tuberculosis strain-independent, efficiently suppressing antigeninduced IFN- $\gamma$ [12]. In this study, we demonstrated that PBMC from MDR-TB patients have significantly higher percentages of $\mathrm{CD} 4^{+} \mathrm{CD} 25^{+} \mathrm{FoxP} 3^{+}$and $\mathrm{CD} 4^{+} \mathrm{CD} 25^{+} \mathrm{CD} 127^{-}$ cells than do HC. We have also evaluated FoxP3 and CTLA-4 expression patterns in ESAT-6-stimulated MDRTB cells. We showed that in cultures from MDR-TB patients, ESAT- 6 increased the regulatory population, as observed by increased FoxP3 expression on $\mathrm{CD} 4^{+} \mathrm{CD} 25^{+} \mathrm{T}$ cells. Because ESAT- 6 increased CD25 ${ }^{+}$cells in MDR-TB patients, we investigated the suppressive capacity of $\mathrm{CD}^{+} \mathrm{CD} 25^{+} \mathrm{T}$ cells. Only MDR-TB patients showed impaired IFN- $\gamma$ production after increasing the ratio of $\mathrm{T}_{\text {reg }}$ conventional $\mathrm{T}$ cells. In addition, we observed that in vitro depletion of the $\mathrm{T}_{\text {reg }}$ population restored the capacity of MDR-TB cells to produce IFN- $\gamma$ in response to ESAT-6.

We would expect that $\mathrm{T}_{\text {reg }}$ cells from patients with $\mathrm{TB}$ could be able to control inflammatory processes affecting the outcome of the disease after treatment. One study [36] has demonstrated that ESAT-6-stimulated cultures from treated $\mathrm{TB}$ patients presented increased percentages of $\mathrm{CD} 4^{+} \mathrm{CD} 25^{\text {high }}$ cells when compared to non-treated patients. We hypothesize that MDR-TB patients have increased $\mathrm{T}_{\text {reg }}$ cell responses because these patients show more advanced and/or chronic disease than do patients in the NR-TB group. To investigate if long-duration antibiotic treatment could affect the frequency of $\mathrm{T}_{\text {reg }}$ cells, we also investigated the phenotype of NTM circulating cells. Despite the differences in pathogenesis, diseases caused by NTM are difficult to treat, and these patients receive antibiotics for a long period of time.

In NTM cells neither ESAT-6 nor PPD were able to increase $T_{\text {reg }}$ numbers, which suggests that in this case the prior NTM exposure was not sufficient to induce a regulatory phenotype after antigenic stimulation (data not shown). It may reinforce the use of recombinant antigens such as ESAT-6 in the BCG vaccine to improve its immunogenicity. In addition, M. avium, PHA or anti-CD3 induce lower concentrations of IFN- $\gamma$, IL-12 and TNF- $\alpha$ in PBMC and/or monocytes from NTM patients when compared to controls [37-39], but analysis of NTM patient cells did not demonstrate an increase in $\mathrm{T}_{\text {reg }}$ circulating cells, which can determine that this phenomenon is specific to MDR-TB cells. 
The source of IL-10 in human tuberculosis is unknown, but an interaction between the mannose receptor of dendritic cells and mannosylated lipoarabinomannan from M. tuberculosis induced the production of high levels of IL-10 [40]. Lee et al. [41] have demonstrated that MDR-TB patients exhibit depression of TNF- $\alpha$ secretion in response to the $30 \mathrm{kDa}$ antigen, an effect modulated by IL-10. In this study, we observed that ESAT-6 increased IL-10 levels significantly in supernatants from MDR-TB cultures when compared to HC and NR-TB. IL-10 blockade decreased the frequency of regulatory cells in ESAT-6-stimulated culture. IL-10 signalling was shown to be necessary for $\mathrm{T}_{\text {reg }}$ stability in an experimental colitis model [42], and previous reports have demonstrated that $\mathrm{CD} 4^{+} \mathrm{CD} 25^{+} \mathrm{FoxP} 3^{+} \mathrm{T}_{\text {reg }}$ cells can be produced from $\mathrm{CD} 4^{+} \mathrm{CD} 25^{-} \mathrm{T}$ cells by culture with antigen and TGF- $\beta$ or IL-10 and TGF- $\beta$ [15]. However, IL-10 or IL-10R $\alpha$ blockade revert the depressed IFN- $\gamma$ production only partially in these cultures (data not shown). Thus, the current data indicate that other mechanisms, such as direct cell contact, might be responsible for the immune suppression induced by $\mathrm{T}_{\text {reg }}$ in ESAT-6-stimulated MDR-TB $\mathrm{T}$ cell cultures.

This study was limited by the fact that all experiments were performed evaluating the immune systemic response, but not the local site of mycobacterial infection. Despite the lower frequencies of mycobacterial-specific T cells in blood, analysis of systemic immune response is easier, and permitted the inclusion of more than 200 patients in the different experiments of this study. In addition, peripheral blood mononuclear $\mathrm{T}_{\text {reg }}$ cells are decreased in newly infected contacts of tuberculosis, due possibly to accumulation in infected lungs [43]. As the infection progresses $\mathrm{T}_{\text {regs }}$ expand to regions of disease sites, as well as in the blood $[44,45]$, and it may be important to evaluate the systemic responses efficiently.

In summary, the data indicate the need for better tests that can discriminate latency from active disease. We must consider the limitations of ESAT- 6 for active disease diagnosis because MDR-TB patients exhibit impaired responses to this antigen, which we have demonstrated to be mediated by increased $\mathrm{T}_{\text {reg }}$ frequencies. Furthermore, we did not find a correlation between NTM disease and an increase in $\mathrm{T}_{\text {reg }}$ phenotype in response to ESAT-6. It is interesting to point out that the mechanisms described here for NTM disease may involve increased TGF- $\beta$ production, whereas in MDR-TB we observed increased IL-10 and increased frequencies of $\mathrm{T}_{\text {reg }}$ cells. Because the numbers of pulmonary disease caused by NTM have increased in the last few years, a thorough understanding of the immune mechanisms involved in NTM pathogenesis is required.

\section{Acknowledgements}

We are grateful to the out-patient unit staff and patients from CRPHF/FIOCRUZ who made this study possible. The study was supported in part by funds from FIOCRUZ, $\mathrm{CNPq}$, by the Intramural Research Program of the NIAID/ NIH (E.S.) and FAPERJ (E.B.O.).

\section{Disclosure}

The authors have no conflicts of interest to declare.

\section{References}

1 Caminero JA. Multidrug-resistant tuberculosis: epidemiology, risk factors and case finding. Int J Tuberc and Lung Dis 2010; 4:382-90.

2 Multidrug and extensively drug-resistant TB (M/XDR-TB): 2010 global report on surveillance and response. WHO Global Report 2010, 71c.

3 Wright A, Zignol M, Van Deun A et al. Epidemiology of antituberculosis drug resistance 2002-07: an updated analysis of the global project on anti-tuberculosis drug resistance surveillance. Lancet 2009; 373:1861-73.

4 Huang CT, Tsai YJ, Wu HD et al. Impact of non-tuberculous mycobacteria on pulmonary function decline in chronic obstructive pulmonary disease. Int J Tuberc Lung Dis 2012; 16:539-45.

5 Winthrop KL, McNelley E, Kendall B et al. Pulmonary nontuberculous mycobacterial disease prevalence and clinical features: an emerging public health disease. Am J Respir Crit Care Med 2010; 182:977-82.

6 Lee W-I, Huang JL, Wei Yeh $\mathrm{K}$ et al. Immune defects in active mycobacterial diseases in patients with primary immunodeficiency diseases (PIDs). J Form Med Assoc 2011; 110:750-8.

7 Demangel C, Garnier T, Rosenkrands I, Cole ST. Differential effects of prior exposure to environmental mycobacteria on vaccination with Mycobacterium bovis BCG or a recombinant BCG strain expressing RD1 antigens. Infect Immun 2005; 73:2190-6.

8 Young SL, Slobbe L, Wilson R, Buddle BM, de Lisle GW, Buchan GS. Environmental strains of Mycobacterium avium interfere with immune responses associated with Mycobacterium bovis BCG vaccination. Infect Immun 2007; 75:2833-40.

9 Flint JL, Kowalski JC, Karnati PK, Derbyshire KM. The RD1 virulence locus of Mycobacterium tuberculosis regulates DNA transfer in Mycobacterium smegmatis. Proc Natl Acad Sci USA 2004; 101:12598-603.

10 Goletti D, Butera O, Bizzoni F, Casetti R, Girardi E, Poccia F. Region of difference 1 antigen-specific CD4+ memory T cells correlate with a favorable outcome of tuberculosis. J Infect Dis 2006; 194:984-92.

11 Lee JS, Song CH, Kim CH et al. Profiles of IFN-gamma and its regulatory cytokines (IL-12, IL-18 and IL-10) in peripheral blood mononuclear cells from patients with multidrug-resistant tuberculosis. Clin Exp Immunol 2002; 128:516-24.

12 Geffner L, Yokobori N, Basile J et al. Patients with multidrugresistant tuberculosis display impaired Th1 responses and enhanced regulatory T-cell levels in response to an outbreak of multidrug-resistant Mycobacterium tuberculosis $\mathrm{M}$ and Ra strains. Infect Immun 2009; 77:5025-34.

13 McDyer JF, Hackley MN, Walsh TE, Cook JL, Seder RA. Patients with multidrug-resistant tuberculosis with low CD4+ $\mathrm{T}$ cell counts have impaired Th1 responses. J Immunol 1997; 158:492-500. 
14 Churina EG, Urazova OI, Novitskiy VV. The role of Foxp3expressing regulatory $\mathrm{T}$ cells and $\mathrm{T}$ helpers in immunopathogenesis of multidrug resistant pulmonary tuberculosis. Tuberc Res Treat 2012; 2012:1-9.

15 Chiacchio T, Casetti R, Butera O et al. Characterization of regulatory $\mathrm{T}$ cells identified as $\mathrm{CD} 4(+) \mathrm{CD} 25$ (high) $\mathrm{CD} 39(+)$ in patients with active tuberculosis. Clin Exp Immunol 2009; 156:463-70.

16 Hall BM, Verma ND, Tran GT, Hodgkinson SJ. Distinct regulatory CD4+T cell subsets; differences between naïve and antigen specific T regulatory cells. Curr Opin Immunol 2011; 23:641-7.

17 Sharma PK, Saha PK, Singh A, Sharma SK, Ghosh B, Mitra DK. FoxP3+ regulatory $\mathrm{T}$ cells suppress effector T-cell function at pathologic site in miliary tuberculosis. Am J Respir Crit Care Med 2009; 179:1061-70.

18 Guyot-Revol V, Innes JA, Hackforth S, Hinks T, Lalvani A. Regulatory $\mathrm{T}$ cells are expanded in blood and disease sites in patients with tuberculosis. Am J Respir Crit Care Med 2006; 173:803-10.

19 Shang S, Gibbs S, Henao-Tamayo M, Shanley CA, McDonnell G et al. Increased virulence of an epidemic strain of Mycobacterium massiliense in mice. PLoS ONE 2011; 6:e24726. doi:10.1371/ journal.pone.0024726.

20 Chimara E, Ferrazoli L, Ueky SY. Reliable identification of mycobacterial species by PCR-restriction enzyme analysis (PRA)- $h s p 65$ in a reference laboratory and elaboration of a sequence-based extended algorithm of PRA- $h s p 65$ patterns. BMC Microbiol 2008; 8:48-56.

21 Fortes A, Pereira K, Antas PR et al. Detection of in vitro interferon-gamma and serum tumour necrosis factor-alpha in multidrug-resistant tuberculosis patients. Clin Exp Immunol 2005; 141:541-8.

22 de Cassan SC, Pathan AA, Sander CR et al. Investigating the induction of vaccine-induced Th17 and regulatory $\mathrm{T}$ cells in healthy, Mycobacterium bovis BCG-immunized adults vaccinated with a new tuberculosis vaccine, MVA85A. Clin Vaccine Immunol 2010; 17:1066-73.

23 Arend SM, Andersen P, van Meijgaarden KE et al. Detection of active tuberculosis infection by $\mathrm{T}$ cell responses to early-secreted antigenic target $6-\mathrm{kDa}$ protein and culture filtrate protein 10 . J Infect Dis 2000; 181:1850-4.

24 Mazurek GH, LoBue PA, Daley CL et al. Comparison of a wholeblood interferon gamma assay with tuberculin skin testing for detecting latent Mycobacterium tuberculosis infection. JAMA 2001; 286:1740-7.

25 Harboe M, Oettinger T, Wiker HG, Rosenkrands I, Andersen P. Evidence for occurrence of the ESAT-6 protein in Mycobacterium tuberculosis and virulent Mycobacterium bovis and for its absence in Mycobacterium bovis BCG. Infect Immun 1996; 64:1622.

26 Arend SM, Thijsen SF, Leyten EM et al. Comparison of two interferon-gamma assays and tuberculin skin test for tracing tuberculosis contacts. Am J Respir Crit Care Med 2007; 175:61827.

27 Esmail H, Barry CE 3rd, Wilkinson RJ. Understanding latent tuberculosis: the key to improved diagnostic and novel treatment strategies. Drug Discov Today 2012; 17:514-21.

28 Lin MY, Reddy TB, Arend SM et al. Cross-reactive immunity to Mycobacterium tuberculosis DosR regulon-encoded antigens in individuals infected with environmental, nontuberculous mycobacteria. Infect Immun 2009; 77:5071-9.
29 Kwon YS, Kim EJ, Lee SH et al. Decreased cytokine production in patients with nontuberculous mycobacterial lung disease. Lung 2007; 185:337-41.

30 Phillips R, Sarfo FS, Guenin-Macé L et al. Immunosuppressive signature of cutaneous Mycobacterium ulcerans infection in the peripheral blood of patients with Buruli ulcer disease. J Infect Dis 2009; 200:1675-84.

31 Dheda K, Booth H, Huggett JF, Johnson MA, Zumla A, Rook GA. Lung remodeling in pulmonary tuberculosis. J Infect Dis 2005; 192:1201-9.

32 Deveci F, Akbulut HH, Turgut T, Muz MH. Changes in serum cytokine levels in active tuberculosis with treatment. Mediat Inflamm 2005; 5:256-62.

33 Dlugovitzky D, Torres-Morales A, Rateni L et al. Circulating profile of Th1 and Th2 cytokines in tuberculosis patients with different degrees of pulmonary involvement. FEMS Immunol Med Microbiol 1997; 18:203-7.

34 Aung H, Wu M, Johnson JL, Hirsch CS, Toossi Z. Bioactivation of latent transforming growth factor beta1 by Mycobacterium tuberculosis in human mononuclear phagocytes. Scand J Immunol 2005; 61:558-65.

35 Lim A, Allison C, Tan DB, Oliver B, Price P, Waterer G. Immunological markers of lung disease due to non-tuberculous mycobacteria. Dis Markers 2010; 29:103-9.

36 Antas PR, Sampaio EP. Another round for the CD4+CD25+ regulatory $\mathrm{T}$ cells in patients with tuberculosis. Am J Respir Crit Care Med 2007; 176:214-5.

37 Ryu YJ, Kim EJ, Lee SH et al. Impaired expression of Toll-like receptor 2 in nontuberculous mycobacterial lung disease. Eur Respir J 2007; 30:736-42.

38 Vankayalapati R, Wizel B, Samten B et al. Cytokine profiles in immunocompetent persons infected with Mycobacterium avium complex. J Infect Dis 2001; 183:478-84.

39 Greinert U, Schlaak M, Rüsch-Gerdes S, Flad HD, Ernst M. Low in vitro production of interferon-gamma and tumor necrosis factoralpha in HIV seronegative patients with pulmonary disease caused by nontuberculous mycobacteria. J Clin Immunol 2000; 20:44552.

40 Chieppa M, Bianchi G, Doni A et al. Cross-linking of the mannose receptor on monocyte-derived dendritic cells activates an antiinflammatory immunosuppressive program. J Immunol 2003; 171:4552-60.

41 Lee JS, Song CH, Lim JH et al. The production of tumour necrosis factor-alpha is decreased in peripheral blood mononuclear cells from multidrug-resistant tuberculosis patients following stimulation with the $30-\mathrm{kDa}$ antigen of Mycobacterium tuberculosis. Clin Exp Immunol 2003; 132:443-9.

42 Murai M, Turovskaya O, Kim G et al. Interleukin 10 acts on regulatory $\mathrm{T}$ cells to maintain expression of the transcription factor Foxp3 and suppressive function in mice with colitis. Nat Immunol 2009; 10:1178-84.

43 Urdahl KB, Shafiani S, Ernst JD. Initiation and regulation of T-cell responses in tuberculosis. Mucosal Immunol 2011; 4:288-93.

44 Herzmann C, Ernst M, Ehlers S et al. Increased frequencies of pulmonary Treg cells in latent M. tuberculosis infection. Eur Respir J 2012. doi: $10.1183 / 09031936.00214611$.

45 Toossi Z, Hirsch CS, Wu M et al. Distinct cytokine and regulatory $\mathrm{T}$ cells profile at pleural sites of dual HIV/tuberculosis infection compared to that in the systemic circulation. Clin Exp Immunol 2011; 163:333-8. 